Journal Of Agriculture and Social Research (JASR) Vol. 8, No.1, 2008

\title{
EFFECTIVENESS OF COUNCIL OPERATIONS AND PARTICIAPTION OF INHABITANTS IN COUNCIL ACTIVITIES IN RURAL MIRABAD, ISFAHAN PROVINCE OF IRAN
}

\section{YASER MOHAMMADI, NAVID LOGHMANI AND M. RAHIMIAN}

\begin{abstract}
This paper discusses council operation, public expectations of people from councils, public participation and coordination of people with councils also factors which affect this kind of participation. Public participation and coordination has been studied in Mirabad village of Tiran and Krun, 2 cities of Esfahan from Iran. This village is located 43 kilometers far from the west of Isfahan, Iran. Its population is more than 70 thousand persons and its climate is cold. The major occupation of its people is agriculture and animal husbandry in this region. The village's council members belong to the average class of community their educational range varies between having elementary school certificate to having licentiate's degree. Data gathered via questionnaire, interview and observation. 30 questionnaires were distributed among Mirabad's people and filled out. Most of the time, along with filling out the questionnaire, an interview was also accomplished and some observation were also made, The results show that council operations such as communicating with people, unanimity, sympathy and getting public trust were effective in receiving public participation and cooperation and also help the councils to do their tasks well. People have good participation in many fields like security maintenance, providing environmental hygiene and maintenance of public installations. The council's members also have good participation in agricultural affairs, providing security and hygiene and pursuing constructional plans.
\end{abstract}

Key words: participation, participation factors, councils operation

\section{INTRODUCTION}

Rural-urban Islamic council election's holding and their establishment in 1999 was the last effort toward fulfilling a national will in Iran, which had 100 year old (Torkamansarabi, 2000).There is no doubt that improvement and structure of councils is a good basis for public participation in management of different affairs (Daftare Motaleate eghtesadi, 2000).

Since there was a lock of historical experiments and insufficient effort of the ancients toward council's settlement, these structures are similar to young tree which has a breakable trunk. Now, in this part of Iran's complex history that government tries to make foundation for a civic community, supporting councils and struggle for their proper start is a public duty. Rural councils can be useful for reaching to the Islamic republic goals via getting public participation and cooperation in country and region construction and development. So, councils and people should have a mutual understanding of the operations and expectations in order to take steps in this way (Kord, 2000). We study the public participation opportunities and all the factors which have some influence on it, in order to promote council operation features and public participation in achieving council formation goals.

This research results will be available for councils, so that they recognize their weakness and strength from the public view and try to overcome their weakness. People can also be aware of council's views and confirm them with their own expectations and participation. The region's councils are doing well from public view, especially in agricultural affaires, maintaining local public security, providing hygiene, providing opportunities for public participation and cooperation participatory while a disaster take place, implanting cultural and religious affaires, supporting unanimity, sympathy and getting public trust, but they were not successful in some other tasks such 
as gathering public taxes, helping local poor, providing opportunities for participation in implementing the governments policies, making the public familiar with councils operations and legal tasks, make them aware of operations progress.

Studding social participation has a long history. Parker said" at first, social participation was a part of social rank. Participation was also seen as a facility for development (Warriner and Pratner, 1965), supporter of pluralistic in mass communities (Nisbet 1957, Kornhauser 1959), a catalyze for local community unity (Harry 1970), a substitute for weak union of family (Wirth 1983, Raizman 1954), political society facto and dominant religious discipline (Warriner and Pratner 1965, Olson 1972) (Parker, 1985). Some of legal council's tasks related to the public cooperation and participation (Organization low, 1998):

$>$ Getting public participation and cooperation with implementers of embassies and organizations which their activities are related to rural affairs and provide required facilities to do these activities.

$>$ Getting public participation and cooperation in cultural and religious affairs implementation.

$>$ Explaining government policies and promoting rural people to implementation.

Studying and recognizing weakness, needs and lack of facilities in rural areas and providing plans and revising and applicable suggestions and presenting council's role in getting public participation. Public participation is one of the main parts of Islamic discipline foundation Mohsenitabrizi, 1990. Islamic council members are also one of the main part councils. Legitimacy of Islamic councils is dependent on public participation. Therefore, their main characteristics are playing attention to the public expectations. Islamic councils have to show their participation and supervisory role in a legal frame. Making more participation opportunities and motivating is one council's responsibilities. In other words, councils should overcome their difficulties by presenting proper solution. This will not be possible till problems and difficulties be presented to authorities and applicable suggestions have been made via public participation, so that every thing can be settled by authorities and public participation).

There is a reverse relationship between participation and centralization councils cause the country governing to be decentralized which is so useful (Azkiya, 2001). Economical and construction planning of government is not effective without public participation and coordination [Daftare Motaleate Eghtesadi, 2000]. Councils can be active in this field as public representatives. Especially getting any guiding public taxes as it can be see in budget law, note 16 by Islamic councils, would be a great help for government and the public to construct rural and areas [home ministry, 1996]. Participation is a voluntary but not a compulsory one. So, people will participate in something that they have interest and trust it [Wolf ,1983]. Councils should communicate with people and make the importance of participation clear.

As a whole, councils are able to making public participation opportunities in different fields. They can communicate with authorities and people more and make this relationship stronger. They can also presenting solution, proposing problems and difficulties and statement of weakness and powerful points in projects, plans and decisions and help the government to decide better and take great steps toward sustainable development and national development [Kord,2000].

\section{METHODOLOGY}

The study used a survey design for data collection. We selected in this research about 90 people from Mirabad village, there people's characteristics were relevant to our index for selection of statically population. It means they all were engage in agronomy, lives stoke, and garden husbandry affaires simultaneous as their acceptation. And with using Cochran's formula, we indicate statistical sample size should be 30 people and then we selected 30 people by method of random sample ling among statically population (90 people). A specific questionnaire was 
developed to measure the council's effectivity and people's cooperation with councils in Mirabad village from Isfahan province in Iran. The questionnaire contained two parts: part I pertained to general demographic variables of the respondents like age, gender, level of education,

Part II contained the scale to measure of council's effectivity and people's cooperation with council. For measuring the council's effectivity and people's cooperation with council, 18 important roles pertaining were identified which were rated on a five point continuum - "very low", "low", "mediate", "high", "very high". The scale has high reliability (Cronbach's alpha=0.85). Instrument was given to the faculty of the department of agricultural extension and education, university of Tehran to test for face validity. Data was analyzed using descriptive and interference statistics such as: percentage, mean score, standard deviation

\section{RESULTS AND DISCUSSION}

About $60 \%$ of the people believed that the council's revenue for getting participation was average but more than $16 \%$ of them think that it was weak and low. The rest $16 \%$ also believe that it was high. More than $36 \%$ of people think that council's revenue in agricultural affairs was average; also about $36 \%$ of them believe that it was weak and low. This shows that the public is satisfied from the council cooperation to some extent and also council has good attention to agriculture affairs as a rural people's income resource, but, still is need to more council's cooperation in rural people's agricultural affaires. The method of gathering taxes in this village was average and low in view of $49 \%$ of the people which shows that councils do not pay enough attention to this field. Councils should improve its revenue in this field and revising the method of gathering taxes.

Table1: Frequency distribution of polling from Mirabad village population about council's effectiveness and people's cooperation with councils

\begin{tabular}{|c|c|c|c|c|c|}
\hline Items & $\begin{array}{l}\text { Very } \\
\text { high }\end{array}$ & High & Average & Very low & Low \\
\hline $\begin{array}{l}\text { 1-extent of success of councils } \\
\text { in getting public participation }\end{array}$ & $1(3.33)$ & $\begin{array}{l}4 \\
(13.33)\end{array}$ & $20(60)$ & $4(13.33)$ & $1(3.33)$ \\
\hline $\begin{array}{l}\text { 2- extent of your cooperation } \\
\text { with councils in agricultural } \\
\text { affairs }\end{array}$ & $1(3.33)$ & $\begin{array}{l}8 \\
(26.66)\end{array}$ & $\begin{array}{l}11 \\
(36.66)\end{array}$ & $8(26.66)$ & $2(6.66)$ \\
\hline $\begin{array}{l}\text { 3- usefulness of the method of } \\
\text { gathering public taxes for } \\
\text { constructing rural area }\end{array}$ & - & $\begin{array}{l}11 \\
(36.66)\end{array}$ & $\begin{array}{l}14 \\
(46.66)\end{array}$ & $3(10)$ & $1(3.33)$ \\
\hline $\begin{array}{l}\text { 4- extent of cooperation with } \\
\text { councils to maintain public } \\
\text { installations }\end{array}$ & $4(13.3)$ & $\begin{array}{l}7 \\
(23.33)\end{array}$ & $\begin{array}{l}13 \\
(43.33)\end{array}$ & $4(13.33)$ & $2(6.66)$ \\
\hline $\begin{array}{l}\text { 5- extent to which councils were } \\
\text { successful in gathering public } \\
\text { participation and cooperation to } \\
\text { do cultural and religious affaires }\end{array}$ & $1(3.33)$ & $\begin{array}{l}7 \\
(23.33)\end{array}$ & $\begin{array}{l}16 \\
(53.33)\end{array}$ & $5(16.66)$ & $1(3.33)$ \\
\hline $\begin{array}{l}\text { 6- extent of cooperation with } \\
\text { councils to do according to } \\
\text { hygiene principles }\end{array}$ & $2(6.66)$ & $12(40)$ & $\begin{array}{l}10 \\
(33.33)\end{array}$ & $4(13.33)$ & $2(6.66)$ \\
\hline $\begin{array}{l}\text { 7- extent to which councils try } \\
\text { to help the poor families }\end{array}$ & $3(10)$ & $12(40)$ & $9(30)$ & $4(13.33)$ & $2(6.66)$ \\
\hline $\begin{array}{l}\text { 8- extent to which councils were } \\
\text { successful in motivating the }\end{array}$ & $3(10)$ & $\begin{array}{l}4 \\
(13.33)\end{array}$ & $12(40)$ & $7(23.33)$ & $3(10)$ \\
\hline
\end{tabular}




\begin{tabular}{|c|c|c|c|c|c|}
\hline $\begin{array}{l}\text { 9- extent to which councils } \\
\text { cooperate with people while a } \\
\text { disaster occurs }\end{array}$ & $1(3.33)$ & $12(40)$ & $\begin{array}{l}11 \\
(36.66)\end{array}$ & $6(20)$ & $1(3.33)$ \\
\hline $\begin{array}{l}\text { 10- extent of cooperation with } \\
\text { councils in overcoming the } \\
\text { difficulties }\end{array}$ & $2(6.66)$ & $\begin{array}{l}7 \\
(23.33)\end{array}$ & $12(40)$ & $7(23.33)$ & $2(6.66)$ \\
\hline $\begin{array}{l}\text { 11- extent to which you can } \\
\text { participate in the affairs of } \\
\text { council's operation and } \\
\text { cooperate with them in these } \\
\text { fields }\end{array}$ & - & $\begin{array}{l}8 \\
(26.66)\end{array}$ & $\begin{array}{l}17 \\
(56.66)\end{array}$ & $4(16.66)$ & $1(3.33)$ \\
\hline $\begin{array}{l}\text { 12- extent of public trust and } \\
\text { effect on the cooperation }\end{array}$ & $5(16.6)$ & $\begin{array}{l}13 \\
(43.33\end{array}$ & $\begin{array}{l}8 \\
(26.66)\end{array}$ & $4(13.33)$ & - \\
\hline $\begin{array}{l}\text { 13- extent of unanimity between } \\
\text { council members and people } \\
\text { effects on their activities and } \\
\text { operations }\end{array}$ & $12(40)$ & $6(20)$ & $\begin{array}{l}7 \\
(23.33)\end{array}$ & $2(6.66)$ & $3(10)$ \\
\hline $\begin{array}{l}\text { 14- extent of council members } \\
\text { making the public aware of the } \\
\text { implementations progress }\end{array}$ & - & 14 & $6(20)$ & $6(20)$ & $4(13.33)$ \\
\hline $\begin{array}{l}\text { 15- extent of council members } \\
\text { agreement regarding } \\
\text { establishment of social relation } \\
\text { to making participation and } \\
\text { cooperation opportunities }\end{array}$ & - & $\begin{array}{l}5 \\
(16.66)\end{array}$ & $\begin{array}{l}16 \\
(53.33)\end{array}$ & $4(13.33)$ & $5(16.66)$ \\
\hline $\begin{array}{l}\text { 16- extent of council's sympathy } \\
\text { with people and effect on their } \\
\text { participation and cooperation }\end{array}$ & $4(13.3)$ & $\begin{array}{l}13 \\
(43.33)\end{array}$ & $12(40)$ & - & $1(3.33)$ \\
\hline $\begin{array}{l}\text { 17- extent of knowledge of } \\
\text { about the council's legal tasks }\end{array}$ & $1(3.33)$ & $\begin{array}{l}8 \\
(26.66)\end{array}$ & $\begin{array}{l}8 \\
(26.66)\end{array}$ & $7(23.33)$ & $5(16.66)$ \\
\hline $\begin{array}{l}\text { 18- extent of public } \\
\text { participation and their } \\
\text { cooperation with councils }\end{array}$ & $6(20)$ & $\begin{array}{l}13 \\
(43.33)\end{array}$ & $\begin{array}{l}5 \\
(16.66)\end{array}$ & $3(10)$ & $2(6.66)$ \\
\hline
\end{tabular}

Figures in parentheses are percentages

Source: Field survey 2007

About half of the people indicated their average participation in public installations and facilities' maintain and according to Banar's finding (2006), the ability of councils for public installment maintain is good. So we can conclude that councils \& people have a good cooperation in the term of public installment maintain. Council's revenue in getting public cooperation in doing cultural and religious affairs was average in people's view and $1 / 3$ of them think that council's revenue in this regard was low. Therefore we can consider councils successful in this field. But councils should be active in strengthen this cooperation. Also, the findings of Askari studies (2001), \& Banar's studies (2006), indicate that councils have high attention to people's cultural and religious affairs.

Regarding participation and cooperation to providing hygiene of environment 46.6 percent of people believe that this cooperation was high and very high, 34 percent of our statically population 


\section{Journal Of Agriculture and Social Research (JASR) Vol. 8, No.1, 2008}

believe that this cooperation was average and $1 / 3$ believe that it was low. This indicates that people urge to their hygiene affaires, and also in this regard they have good level of participation with council. The research findings of Banar (2006), approve this result and this findings indicate that in the term of hygiene attains following up, there is a good cooperation between people and council.

In public view, council's revenue in getting public participation and cooperation to help the poor was average. These shows, in this field, the council should improve its activity quantitatively and qualitatively and maybe, one of the reasons for council revenue in the term of doesn't helping poor people is credit and budget shortage.

Regarding pursuing the people in order to implement government Policies are not an equal distribution between different answers. It means that people have different views about council activities in this field which shows the requirement of a general revision in this regard by councils. About $40 \%$ of statically population thinks that council cooperation and participation is good while a disaster take place. More than $36 \%$ of them think it is average. Dependent On which phenomenon that they consider as disasters, they believe that council revenue is more than average toward a high level.

Also, 40\% of people have an average participation in solving council problems. The rest have low participation this result show that people is interesting in solving council problems to some extent and they urge to council's existence \& development, and also they believe for council's productivity improvement by solving council's problem. Research of findings of Khooshegir (2003), indicate that the level of participation of people with council due to problem solving has been average. More than half of the people have an average information regarding council activity fields. Council should make the public familiar with their activity fields by holding meetings with the people. It seems that the awareness of people regarding tasks and functions of councils by means of mass media is necessary.

About $60 \%$ of individuals; indicate that getting public trust is one of the main criteria which are affective on people and councils relationship. This shows that council should get public trust to be successful in implementing its tasks and making good relationship with people. Regarding great influence of council unanimity with people in their activities, $60 \%$ of people believed the same. This result shows that the ability to imagining oneself in other shoes (feeling of unanimity) by councils has a great effect on their activities.

About half of the statistical population was satisfied with the method of making them aware of activities progress. Satisfactions of $20 \%$ of people were average and the rest $(20 \%)$ believes that councils Act weakly in this field. Council members should make some new decisions regarding making people aware of activities progress, because people awareness will increase their cooperation and participation. More than half of statistical population thinks that councils member were average in establishment of social relations to make participation opportunities. But more than $30 \%$ of people believe than council revenue was weak in this field. One of the major activities of councils to reach their goals is getting public participation in various fields. Establishment of a social relation is required to implement their activities and councils should pay enough attention to this.

About half of the people think that council unanimity has effect on their participation. Here, the necessity and importance of unanimity in getting public participation and cooperation will be clear. This issue makes the council to be active in providing unanimity with people. Research findings of Perth \& Kinross Tenants and Residents Federation, (2004) indicate that for decision making about any fields, participation and consulting with Tenants is so necessary and also paying attention to their view points should be as a part of decision making process. Almost $30 \%$ of people have average information about legal tasks of councils. $40 \%$ of them think that they have little information the basis of council operations is their legal tasks. If the people have little information 
about that, there would be a disturbance in councils operation and their cooperation with the public .so, council should take steps toward making the people aware.

Half of the people think that participation in election is effective on public participation and cooperation. Almost $16 \%$ of them think that it has a minor influence on public participation. Councils should try to provide an atmosphere that people can participate in council's elections freely, because participation in elections will in fluency public participation and cooperation.

\section{Presence in meeting:}

Presence in meeting as a symbol of participation in decision making is a variable.

In our statistical population, this variable's mean is 7.5 and its standard deviation is 4.2.

Table1: distribution of frequency of individuals in this study, regarding their attendance in council's meetings.

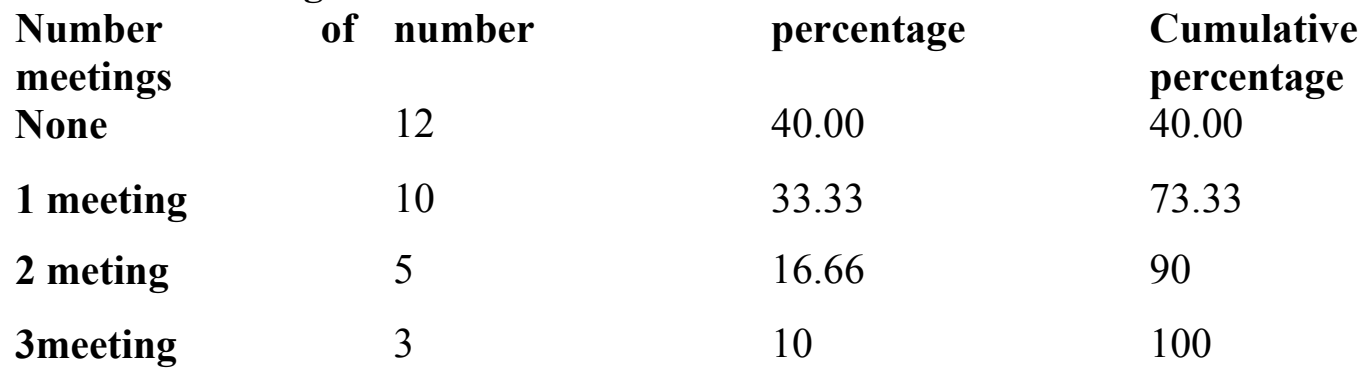

Source: Research finding, (2007)

Table data show that $40 \%$ of individuals were attending no meetings. $33.3 \%$ of them were attending one 2 meetings $.16 .7 \%$ were attending meeting and $10 \%$ were attending 3 or more meetings that the results show that their participation was average toward low. Also the research findings of Khooshegir (2003) indicate that about $61.6 \%$ of respondents have not any attendance in council meeting or one attendance. This shows that the needs for more participation in this field. and maybe this is due to lack of awareness of people of council activities and tasks.

\section{Presenting views and suggestion in meetings:}

Presenting views and suggestion in meetings as a symbol of participation in decision making is a variable. In our statistical population, this variable's mean is 6 and its standard deviation is 3.16. 
Table 2: Distribution of individual's frequency participated in this study, based on their recommendation presentation in the council's meetings.

\begin{tabular}{|l|l|l|l|}
\hline $\begin{array}{l}\text { Number of } \\
\text { suggestion }\end{array}$ & Frequency & Percentage & $\begin{array}{l}\text { Cumulative } \\
\text { percentage }\end{array}$ \\
\hline None & 10 & 33.33 & 33.33 \\
\hline $\mathbf{1}$ & 8 & 26.66 & 60 \\
\hline $\mathbf{2}$ & & 20 & 80 \\
\hline $\mathbf{3}$ & 6 & 13.33 & 93.3 \\
\hline $\mathbf{4}$ or more & 4 & 6.66 & 100 \\
\hline
\end{tabular}

Source: Research finding, (2007)

Table 2 shows that about $33.3 \%$ of individuals had no roles in decision making related councils plans. About $26.7 \%$ had just one suggestion. $20 \%$ of them had only 2 suggestions. Also, $13.3 \%$ of individual had 3 suggestion and only $2 \%$ of person have 4 or more suggestion in decision making.

\section{CONCLUSION}

The results show that council operations such as communicating with people, unanimity, sympathy and getting public trust were effective in receiving public participation and cooperation and also help the councils to do their tasks well. People have good participation in many fields like security maintenance, providing environmental hygiene and maintenance of public installations. The council's members also have good participation in agricultural affairs, providing security and hygiene and pursuing constructional plans.

\section{RECOMMENDATIONS}

A basis should prepare for public participation in decision making. Councils can be good basis in this regard. But this needs a cultural training and movement, so that councils could have a friendship relation with government legislator organizations and with people .it means that decision making should be common in councils and some parts of implementation process left to them.

Implementer and supervisory roles should also be added to council's responsibilities. Islamic council members as rural managers should increase their knowledge and awareness regarding various, especially about their tasks and duties. This could end with more output and be the basis of sustainable development in rural area in a long time period. Rural councils should transfer people orientation to the lowest layer of society and make public participation and management stronger. They could give some of management responsibilities to the public via decentralization and balance public expectations and government expectations. Rural council's members should know that despite of all limitations and poverty, what can be as a capital for councils, is public trust. Presenting training programs which provide a basis for rural population participation in activities and in participatory units and also giving responsibilities to them. Pay enough attention to providing an atmosphere in which trust exist between inter individual and organizational level. This will increase social participation.

\section{REFERENCES}

Askari, M. (2001), modeling of rural councils for rural development in Ilam county, thesis of MSc, Economic and Agricultural Development faculty, Agricultural Extension and Education Department. 


\section{Journal Of Agriculture and Social Research (JASR) Vol. 8, No.1, 2008}

Azkia, M. and Ghafari G. (2001), investigation of the relationship between rural social unity and organized social participation in rural areas of Kashan .agricultural economical and development magazine . no 36 .p.175.

Banar, R. (2006), Investigation of responsibility capacity of rural Islamic councils, Thesis of MSc, Jihade-Daneshgahi press.

Dafare motaleate eghtesadi of jihad-e- Agriculture ministry. (2000), Investigation of rural participation causes in development palns. Tehran, minisry of jihad-e-Agriculture.

Falsafi, Peiman. (2005), "Investigating about Council's corruptions ". Magazine of Salehine Rusta. No 188. p.14.

Home Office, (1996), organization tasks, Islamic council's election regulation.

Islamic republic of Iran constitution along with corrections of revision council (1989), Nashr and Tahghighat Zekr.

Kord, R. (2005),"Council's success in getting public participation on affaires of village, "Magazine of Salehine Rusta. No 180, p.17-18.

Khooshegir, M. (2003), Investigation of effective factors on rural Islamic councils operation in Savojbalagh county, thesis of MSc, Economic and Agricultural Development faculty, Agricultural Extension and Education Department.

MohseniTabrizi, A. (1990), Investigating rural people participation fields and also, rural people participation relationship to agricultural extension.

Oakley, P. and David, M. (1991), Participation methods in rural development, translation: Mansur Mahmoodnezad. Jihad publications- Tehran.

Oakley, P. et al. (1999), Protects with people the practice of participation in rural development, ILO, Geneva

Parker , R. (1985), Measuring social participation, American sociological review, Vol. 84 , Issue , 864-873.

Perth \& Kinross Tenants and Residents Federation. (2004), Perth \& Kinross Council Tenant Participation Strategy.http://www.pkc.gov.uk/NR/rdonlyres/C758C3C2-5D8D-4267-B4FD69BA76644239/0/TPStrategy_AppendixA_Jan04.pdf

TorkamanSarabi, M. (2001), "Organization of Council ". Salehine Rusta magazine. No 186 .p. 1417.

Wolf, M. (1983), participation the view from above, UNRISD, Geneva. 